\title{
CELL NUCLEAR ALTERATIONS IN MYOTONIC DYSTROPHY
}

\author{
MANUELA MALATESTA (*), MARZIA GIAGNACOVO $(* *)$
}

RIASSUNTO. - Nel nucleo cellulare i trascritti primari dei geni subiscono varie modificazioni molecolari per diventare RNA maturi, pronti per essere esportati nel citoplasma. Questi eventi molecolari sono ordinati cronologicamente e spazialmente, e avvengono prevalentemente in strutture contenenti ribonucleoproteine (RNP). Difetti nella maturazione dell'RNA sono stati associati a patologie che provocano distrofia muscolare: nelle distrofie miotoniche di tipo 1 (DM1) e di tipo 2 (DM2), le caratteristiche multisistemiche (ad esempio, miotonia, distrofia muscolare, cardiomiopatia dilatativa, difetti della conduzione cardiaca, cataratta, insulino-resistenza, anomalie sierologiche specifiche) che contraddistinguono queste patologie sono causate dall'espansione di due distinte sequenze nucleotidiche $((\mathrm{CTG}) \mathrm{n}$ nel gene DMPK del cromosoma 19q13 nella DM1, e (CCTG)n nel gene ZNF9 del cromosoma 3q21 nella DM2). Associando tecniche biomolecolari e citochimiche, è stato dimostrato che i meccanismi di base in entrambe le DM consistono nel sequestro nucleare degli RNA espansi: i trascritti contenenti CUG e CCUG si accumulano in foci intranucleari rispettivamente nella DM1 e nella DM2, ed alterano la regolazione e la localizzazione intranucleare delle proteine CUGBP1 e MBLN1, necessarie per la maturazione fisiologica del pre-RNA messaggero (mRNA). Mediante tecniche immunocitochimiche in microscopia ottica ed elettronica, il nostro gruppo ha dimostrato che, nella DM2, i foci contenenti MBNL1 sequestrano anche snRNPs e hnRNPs, fattori di splicing coinvolti nelle fasi precoci della maturazione dei trascritti, a supporto dell'ipotesi che il fenotipo patologico multifattoriale dei pazienti distrofici sia dovuto ad una generale alterazione dei processi maturativi posttrascrizionali del pre-mRNA. Abbiamo anche dimostrato che, nei muscoli scheletrici di pazienti affetti da DM1 e DM2, diversi fattori di splicing e di cleavage si accumulano

(*) Dipartimento di Scienze Neurologiche e del Movimento, Sezione di Anatomia e Istologia, Università degli Studi di Verona, Strada Le Grazie 8, 37134 Verona, Italy. Tel.: +39.045.8027157 - Fax: +39.045.8027163.

E-mail: manuela.malatesta@univr.it

${ }^{(* *)}$ Dipartimento di Biologia e Biotecnologie "Lazzaro Spallanzani”, Laboratorio di Biologia cellulare e Neurobiologia, Università degli Studi di Pavia, Pavia, Italy. 
nei mionuclei, suggerendo disfunzioni nei processi di maturazione del pre-mRNA simili alle alterazioni nucleari tipiche della sarcopenia (la perdita di massa e funzione muscolare che si verifica fisiologicamente con l'invecchiamento). Inoltre, in uno studio in vitro, abbiamo osservato che i mioblasti derivati da cellule satellite di pazienti affetti da DM2 mostrano caratteristiche tipiche della senescenza e disfunzioni dei processi maturativi del pre-mRNA più precocemente dei mioblasti di individui sani. Nel loro insieme, questi dati suggeriscono l'esistenza di meccanismi nucleari comuni alla base delle alterazioni muscolari in diverse condizioni patologiche.

$* * *$

AвSTRACT. - In the cell nucleus, genes are transcribed, and the primary transcripts undergo molecular processing which generates mature RNAs to be exported to the cytoplasm. The events leading to the formation of mature RNAs are chronologically and spatially ordered, and they mostly occur on distinct ribonucleoprotein (RNP)-containing structures. Defects in the RNA maturation pathways have been related to diseases leading to muscle dystrophy: in myotonic dystrophy type 1 (DM1) and type 2 (DM2), the characteristic multisystemic features (e.g., myotonia, muscular dystrophy, dilated cardiomyopathy, cardiac conduction defects, cataracts, insulin-resistance, and disease-specific serological abnormalities) are caused by the expansion of two distinct nucleotide sequences: (CTG) $n$ in the 3' untranslated region of the DMPK gene on chromosome 19q13 in DM1, and (CCTG)n in the first intron of the ZNF9 gene on chromosome $3 \mathrm{q} 21$ in DM2. Combining biomolecular and cytochemical techniques, it has been demonstrated that the basic mechanisms of both DMs reside in the nuclear sequestration of the expanded RNAs: CUG- and CCUG-containing transcripts accumulate in intranuclear foci in DM1 and DM2 cells respectively, and alter the regulation and intranuclear localization of the RNA-binding proteins CUGBP1 and MBLN, which are necessary for the physiological processing of pre-mRNA. Using immunocytochemical techniques at light and electron microscopy, we have demonstrated that MBNL1-containing foci in DM2 cells also sequester snRNPs and hnRNPs, splicing factors involved in the early phases of transcript processing; this strengthens the hypothesis that the multifactorial phenotype of dystrophic patients could be due to a general alteration of the pre-mRNA post-transcriptional pathway. Interestingly, we also demonstrated that, in skeletal muscles of DM1 and DM2 patients, splicing and cleavage factors accumulate in myonuclei, suggesting an impairment of pre-mRNA processing reminiscent of the nuclear alterations typical of sarcopenia (i.e. the loss of muscle mass and function physiologically occurring during ageing). Moreover, in an in vitro study, we observed that satellite-cell-derived DM2 myoblasts show cell senescence alterations and impairment of the pre-mRNA maturation pathways earlier than the myoblasts from healthy patient. These results suggest possible common cellular mechanisms responsible for skeletal muscle wasting in different pathologies. 


\section{CELL NUCLEAR ARCHITECTURE AND} IN SITU ANALYSIS OF RNA PROCESSING

In eukaryotic cells, gene primary transcripts (pre-mRNAs) undergo extensive modifications before generating mature mRNA to be exported to the cytoplasm. This processing occurs in the spliceosome, a molecular complex composed by five small nuclear ribonucleoproteins (snRNPs) (U1, U2, U4/U6 and U5 snRNPs) and many nonsnRNP splicing factors as well as by a large number of regulating factors. After removal of introns, the maturation of 3' ends must be completed, and this requires the involvement of several cleavage and polyadenylation factors (Wahle and Rüegsegger, 1999).

The events leading to the formation of mature mRNA occur mostly co-transcriptionally, thereby implying the simultaneous presence of different molecules on the transcriptional sites. The structural counterpart of these molecular complexes is represented by the perichromatin fibrils $(\mathrm{PF})$, fine fibrillar structures mainly distributed at the edge of condensed chromatin (the so-called perichromatin region); PF represent the in situ form of nascent transcripts (reviews in Fakan, 1994, 2004) as well as of their splicing (Cmarko et al., 1999) and 3' end processing (Schul et al., 1996; Cardinale et al., 2007). PF are therefore highly sensitive markers not only for monitoring the transcriptional and processing rate of a cell, but also for identifying the maturation level of (pre)mRNA occurring in the nucleus in functional correlation with the cellular metabolic state (Biggiogera et al., 2008).

The pathways followed by the maturating pre-mRNA before to be exported to the cytoplasm are not completely known: it is likely that one part would migrate through the interchromatin space towards the nuclear pores as PF, while another part would be carried by the perichromatin granules (PG). These roundish RNP structures, preferentially occurring in the perichromatin region (Monneron and Bernhard, 1969), would act as both vectors and storage sites of already spliced pre-mRNA (Fakan, 1994, 2004), and modifications in the number and/or molecular composition of PG are markers of alterations of the intranuclear pathways (e.g. Puvion et al., 1977; Puvion-Dutilleul and Puvion, 1981; Lafarga et al., 1993; Zancanaro et al., 1993). The interchromatin granules (IG), occurring as clusters in the interchromatin space, represent storage, assembly and phosphorylation sites for 
transcription and splicing factors, but they are not directly involved in pre-mRNA modifications (Puvion and Puvion-Dutilleul, 1996; Bogolyubov et al., 2009).

Therefore, the events leading to the formation of mature RNAs are chronologically and spatially ordered, and they mostly occur on distinct RNP-containing structures (Figure 1). The specific intranuclear location of these RNP components, clearly recognizable by the cytochemical EDTA technique (Bernhard, 1969), is a necessary prerequisite for the correct processing of nuclear RNAs to occur, so that whenever transcription and/or splicing are altered, the organization, composition, and intranuclear location of RNP-containing structures are also affected (Biggiogera et al., 2004, 2008; Malatesta et al., 2008, 2010a). As a consequence, the in situ analysis of the nuclear organization and molecular composition not only provides information about the DNA/RNA pathways which govern the cellular metabolism, but may reveal the occurrence of dysfunctions related to pathological phenotypes, also in skeletal muscle diseases (Malatesta and Meola, 2010).

\section{CELL NUCLEAR ALTERATIONS IN MYOTONIC DYSTROPHY}

Myotonic dystrophies (DMs) are autosomal dominant disorders characterised by a variety of multisystemic features including muscular dystrophy with increased number of centrally located or clumped nuclei in muscle fibres (Vihola et al., 2003), myotonia (muscle hyperexcitability), dilated cardiomyopathy, cardiac conduction defects (Bachinski et al., 2003), insulin-resistance, cataracts (Meola and Moxley, 2004), and disease-specific serological abnormalities (Savkur et al., 2001, 2004; Day et al., 2003). Two forms of DM are known: the more severe DM1-Steinert's disease (OMIM 160900) is caused by an expanded (CTG)n nucleotide sequence in the 3' untranslated region of the Dystrophia Myotonic Protein Kinase (DMPK) gene (OMIM 605377) on chromosome 19q13 (Brook et al., 1992; Fu et al., 1992; Mahadevan et al., 1992); the second form, DM2 (OMIM 602688) displays a milder clinical phenotype and is caused by the expansion of the tetranucleotidic repeat (CCTG)n in the first intron of the Zinc Finger Protein (ZNF)-9 gene (OMIM 116955) (Liquori et al. 2001) on chromosome 3q21 (Ranum et al., 1998). 


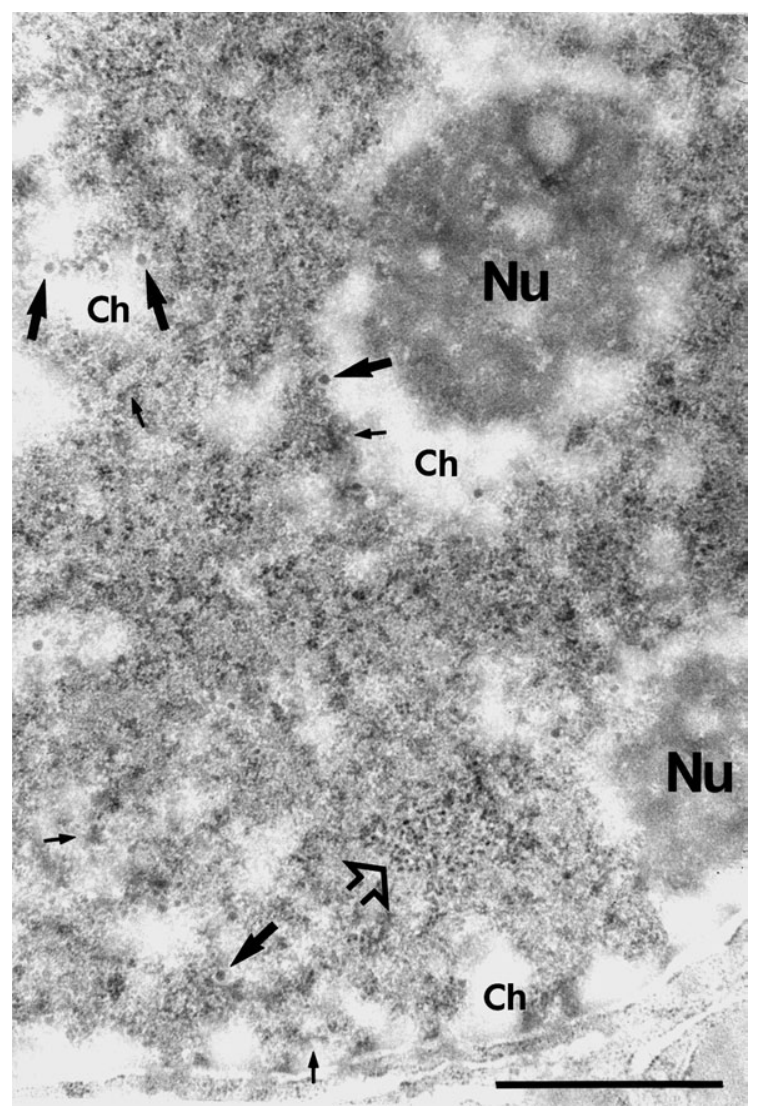

Figure 1. An ultrathin section of a rat hepatocyte nucleus after glutaraldebyde fixation and Epon embedding. Following the EDTA staining which preferentially contrast RNP constituents (Bernhard, 1969), nucleoplasmic structures such as perichromatin fibrils (some are indicated by small arrows), perichromatin granules (large arrows) and clusters of interchromatin granules (open arrow) are easily visualized; also the nucleoli (Nu) remain well contrasted, whereas chromatin (Ch) is bleached and appears light grey. Bar: $1 \mu \mathrm{m}$. (From Fakan S, 2004. Eur J Histochem 48:5-14; reproduction authorized by the Editor)

Defects in the RNA maturation pathways have been related to both DM forms. Combining biomolecular and cytochemical techniques, it has been demonstrated that the expanded-CUG- and CCUG-containing transcripts in DM1 and DM2 cells are retained in the cell nucleus, and accumulate in the form of focal aggregates (Liquori et al., 2001). These 
nuclear foci of mutant mRNA specifically sequester the alternative splicing regulators CUG-binding protein 1 (CUGBP1) and muscleblind-like 1 (MBLN1) protein (Miller et al., 2000; Ladd et al., 2001; Fardaei et al., 2002; Holt et al., 2009; Jones et al., 2011), which are necessary for the physiological processing of pre-mRNA, especially for contractile protein synthesis (Llorian and Smith, 2011). The sequestration into foci leads to nuclear depletion and loss of function of these important factors (Mankodi et al., 2001). These focal aggregates are considered as a biomolecular feature of DMs, and have been detected in several adult tissues and cell cultures by in situ hybridization (Taneja et al., 1995; Liquori et al., 2001; Mankodi et al., 2003, 2005; Cardani et al., 2004, 2006, 2009; Schoser et al., 2004; Wheeler and Thornton, 2007). The molecular composition of nuclear foci is far from being fully elucidated. Our group, by combining immunofluorescence and immunoelectron microscopy on cultured myoblasts from DM patients, has demonstrated that foci also sequester hnRNPs and snRNPs, i.e. splicing factors involved in the early phases of the pre-mRNA processing (Perdoni et al., 2009) (Figures 2 and 3). The sequestration of these splicing factors strengthens the hypothesis that the multifactorial phenotype of dystrophic patients could be due to a general alteration of the pre-mRNA post-transcriptional pathway.
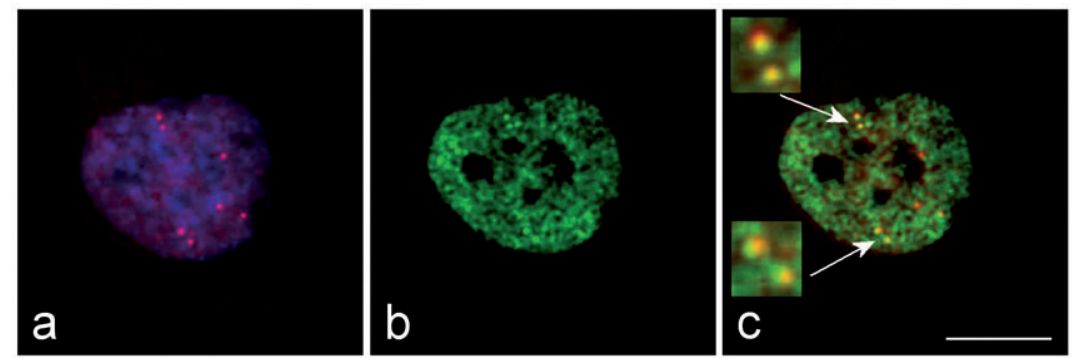

Figure 2. The immunolabelling for MBNL1 (red fluorescence in a) and that for the bnRNP core protein (green fluorescence in b) frequently co-locate (yellow fluorescence in the merged image, $c$ ). In the insets in panel c), the co-labelled foci indicated by the arrows are shown at a higher magnification. In panel a), the counterstaining with Hoechst 33258 of nuclear DNA is also shown (blue fluorescence). Bar: $10 \mu \mathrm{m}$.

In a very recent study, by using biochemical, immunocytochemical and morphometric techniques, we investigated the fate of MBNL1-containing foci in proliferating and in non-cycling cultured skin fibroblasts 
from DM2 patients (Giagnacovo et al., 2012). We demonstrated that MBNL1 associates to the transcribed RNA expanded sequences and accumulate in the nuclear foci during interphase; at mitosis, the foci relocate to the cytoplasm where they remain until the following early G1, when cytoplasmic foci undergo degradation; at the same time, newlyformed foci develop in the nucleus as a consequence of de novo accumulation of expanded RNAs. In DM2 proliferating fibroblasts, the cyclic release from the nucleus of the foci and their cytoplasmic degradation actually prevent a massive intranuclear sequestration of MBNL1 and other protein factors involved in pre-mRNA processing. On the contrary, when fibroblasts loose their proliferation capabilities and stop cycling, the nuclear foci do not undergo relocation/degradation and undergo progressive increase in number and size, due to a continuous accumulation of both expanded RNAs and protein factors among which MBNL1.
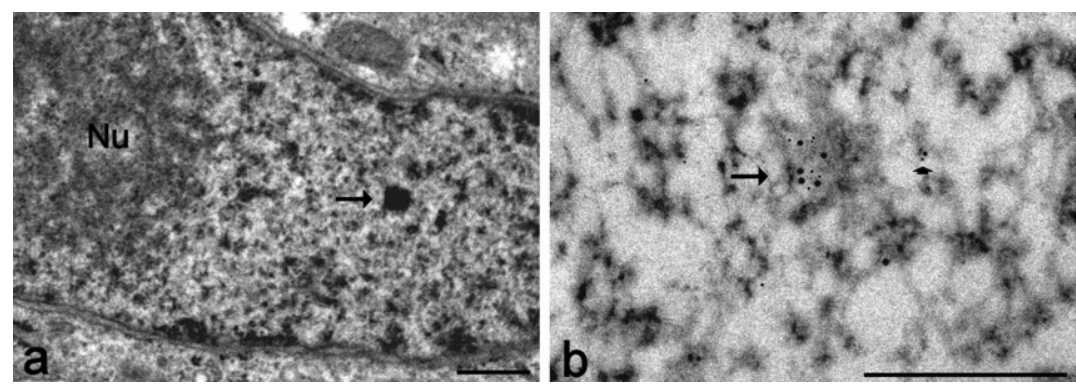

Figure 3. Transmission electron micrographs of myoblast nuclei from DM2 patients. a): Conventional ultrastructural morphology (glutaralaldebyde-fixation, $\mathrm{OsO}_{4}$ post-fixation, Epon embedding), lead citrate staining: the focus appears as a strongly electron-dense roundish nuclear domain (arrow) located in the nucleoplasm. b): Immunoelectron microscopy (paraformaldebyde fixation, Unicryl-embedding), EDTA staining: dual immunolabelling with anti-MBNL1 (12 $\mathrm{nm}$ gold particles) and anti-snRNP (6 $\mathrm{nm}$ gold particles) antibodies; the probes co-locate in the focus (arrow) and on perichromatin fibrils (arrowhead). Nu, nucleolus. Bars: $0.5 \mathrm{~mm}$.

Interestingly, measurements on muscle biopsies taken from the same DM2 patients at different ages demonstrated that, in the nuclei of myofibres, the MBNL1-containing foci become larger with increasing patient's age (Giagnacovo et al., 2012).

This dynamic behaviour of nuclear foci is compatible with the evidence that in DM patients the most affected organs or tissues are those 
where non-renewing cells are mainly present, such as the skeletal muscle, heart and the central nervous system, whereas cells from self-renewing tissues (such as skin fibroblasts or layering epithelial cells) are much less affected.

In addition to the formation of intranuclear foci, DM1 and DM2 cells show an altered distribution of nuclear RNP-containing structures and molecular factors responsible for pre-mRNA transcription and maturation. In particular, by means of ultrastructural immunocytochemistry on skeletal muscle biopsies from DM1 and DM2 patients, we have recently demonstrated (Malatesta et al., 2011b) that splicing and cleavage factors accumulate in the intranuclear functional sites where they are usually located (i.e., hnRNPs and CStF on PF; snRNPs on PF and IG) (Figure 4). Accordingly, new results on the intranuclear distribution of MBNL1 in myonuclei of skeletal muscle from DM1 and DM2 patients revealed an accumulation of this alternative splicing factor on $\mathrm{PF}$ and also on IG (where it does not usually occur in healthy subjects) (Malatesta et al., manuscript in preparation). This accumulation could hamper the functionality of the splicing machinery and slow down the intranuclear molecular trafficking thus reducing the metabolic activity of myonuclei, consistent with recent findings demonstrating a reduced protein synthesis in DM1 and DM2 myoblasts (Salisbury et al., 2009; Huichalaf et al., 2010).
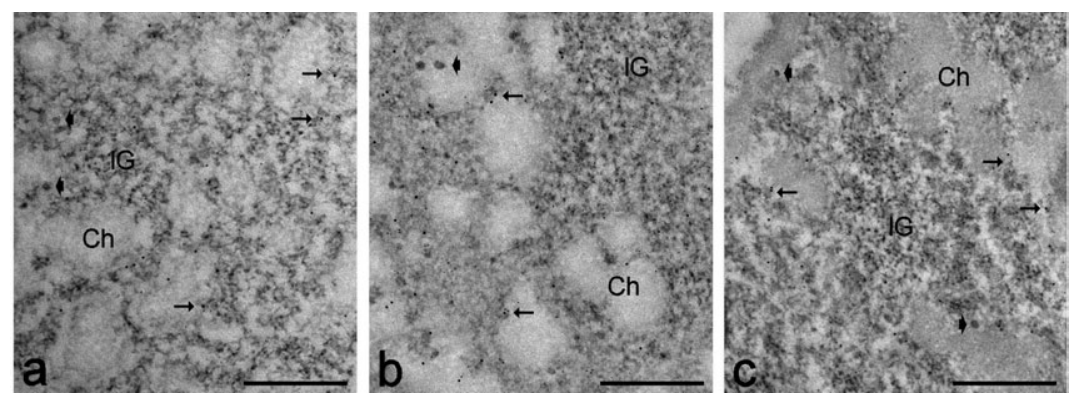

Figure 4. Myonuclei of biceps brachii biopsies from bealtby (a), DM1 (b) and DM2 (c) patients; double immunolabelling with anti- $(S m) \operatorname{snRNP}(6 \mathrm{~nm}$ gold particles) and antibnRNP (12 nm gold particles) antibodies; EDTA staining. Both probes label perichromatin fibrils (arrows); in addition, the anti-(Sm)snRNP antibody labels interchromatin granules (IG). Note the lower labelling density in the healthy sample (a) in comparison to DM1 (b) and DM2 (c) myonuclei. Ch, condensed chromatin; arrowheads, perichromatin granules. Bars: $0.5 \mu \mathrm{m}$. 
MYOTONIC DYSTROPHY AND AGEING:

COMMON MECHANISMS FOR SIMILAR EFFECTS?

Ageing is associated with a progressive loss of muscle mass, strength and function, known as sarcopenia (Ryall et al., 2008; Thompson, 2009; Cruz-Jentoft et al., 2011). Interestingly, under this condition the skeletal muscle is characterized by grouped atrophy, fiber size variability and centrally located nuclei (Endstrom et al., 2007), similarly to muscles affected by DM. In addition, some cell nuclear alterations described in myofibres of sarcopenic muscles are reminiscent of those found in DM cells. In fact, although no foci have been observed, factors involved in pre-mRNA post-transcriptional processing have been found to accumulate on PF and, sometimes, to move to IG, where they do not usually locate (Malatesta et al., 2009, 2010b, 2011a). This intranuclear accumulation/delocalization of RNP structures containing splicing and cleavage factors has been found not only in aged skeletal muscle but also in other tissues (e.g., liver, brain) from old rodents (Malatesta et al., 2003, 2004, 2005, 2007, 2010a; BertoniFreddari et al., 2004). This suggests that in ageing cells the entire production chain of mRNA, from synthesis to cytoplasmic export, becomes less efficient, likely contributing to the reduced cell responsiveness to metabolic stimuli which is typical of elderly. This loss of responsiveness would be particularly serious in skeletal muscle cells, where a misregulated protein turnover would result in a structural imbalance between muscle protein synthesis and degradation (review in Koopman, 2009).

In a recent study (Malatesta et al., 2011c) we investigated in vitro the structural and functional features of satellite-cell-derived myoblasts and we observed that DM2 myoblasts show cell-senescence alterations such as cytoplasmic vacuolisation, reduction of the proteosynthetic apparatus, accumulation of heterochromatin and impairment of the pre-mRNA maturation pathways earlier than myoblasts from healthy patients (Figures 5 and 6); moreover, DM2 myoblasts generate myotubes characterised by structural defects similar to senescent healthy myotubes (Giagnacovo et al., 2011). The early occurrence of senescence-related features in satellite cellderived myoblasts would therefore reduce the regeneration capability of DM2 satellite cells, thus contributing to the muscular dystrophy in DM2 patients. 

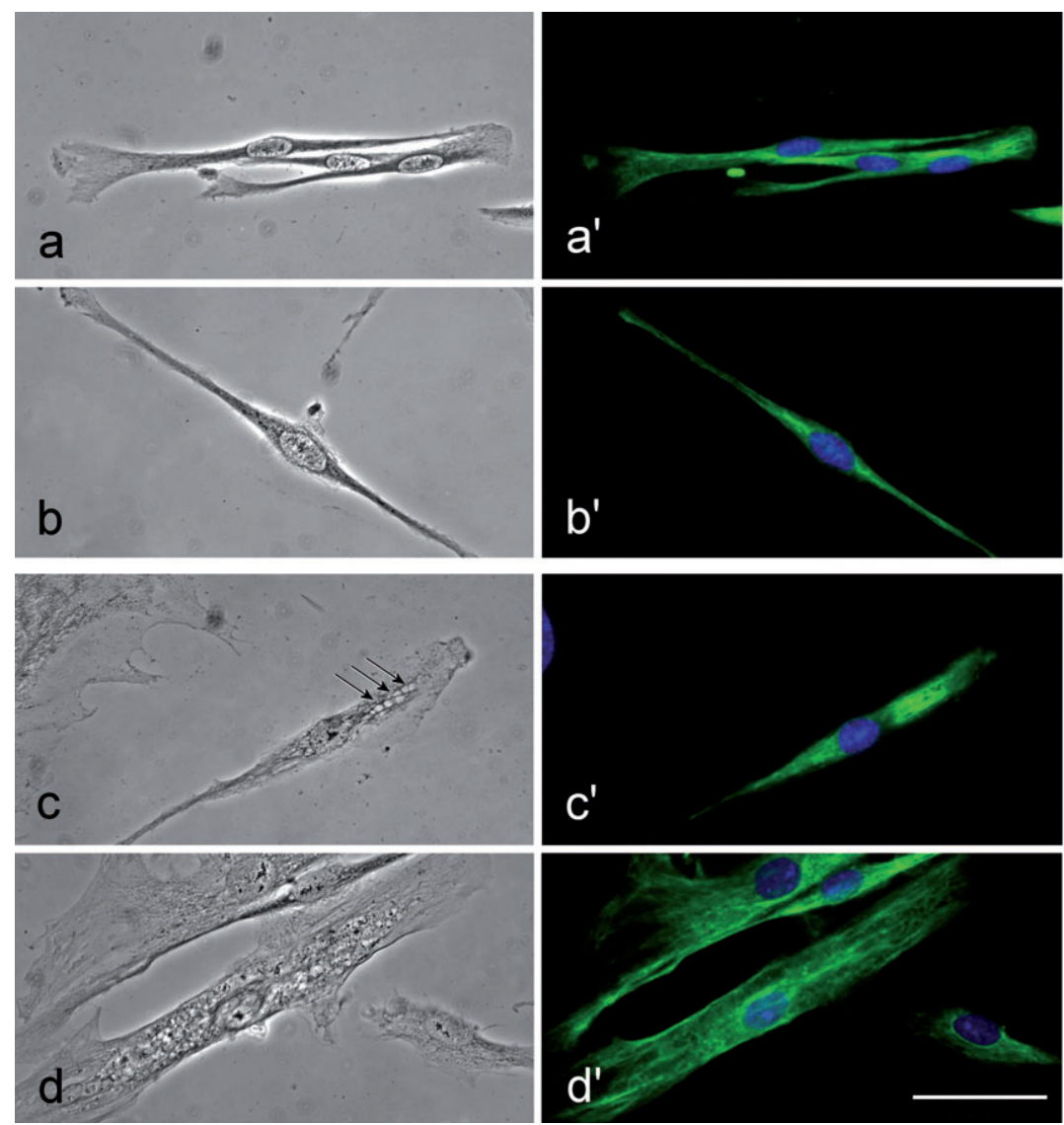

Figure 5. Phase contrast and fluorescence micrographs of myoblasts from bealthy ( $a, a$ ' and $\left.b, b^{\prime}\right)$ and DM2 patients $\left(c, c^{\prime}\right.$ and $\left.d, d^{\prime}\right)$ at the second ( $a$ and $c$ ) and the fourteenth ( $b$ and $d$ ) passage in culture, after immunolabeling for desmin. Myoblasts are characterized by their thin and elongated shape, and exhibit immunopositivity for desmin (green fluorescence). Nuclear DNA was counterstained with Hoechst 33258 (blue fluorescence). It is worth noting that already at an early passage in culture, DM myoblasts show cytoplasmic vacuolization (arrows in c) which become prominent at late passages (d). Bar: 20 um 

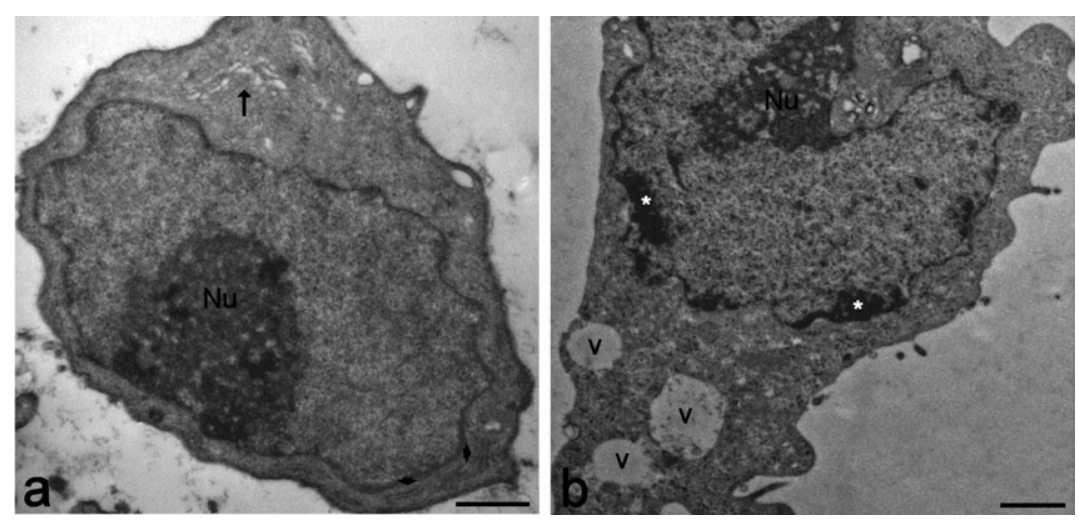

Figure 6. Transmission electron micrographs of myoblasts from healthy (a) and DM2 (b) patients at the second culture passage; conventional ultrastructural morphology (glutaralaldebyde-fixation, $\mathrm{OsO}_{4}$ post-fixation, Epon embedding), lead citrate staining. The myoblast in a) shows a nucleus with scarce heterochromatin, rough endoplasmic reticulum (arrowheads) and a well developed Golgi complex (arrow). The myoblast in b) shows a nucleus with evident heterochromatin (asterisks) and cytoplasmic vacuoles (v). Nu, nucleolus. Bars: 1 um.

\section{CONCLUDING REMARKS}

Based on the cytochemical and ultrastructural evidence, the skeletal muscle of DM patients seems to share intriguing similarities with the muscle from aged mammals, with special reference to the alterations in the nuclear RNP-containing structures involved in pre-mRNA transcription and splicing. This opens interesting perspectives on the role of the RNP nuclear components in the onset of muscle cell dysfunctions and encourages comparative studies aimed at detecting common cellular mechanisms at the basis of skeletal muscle wasting.

\section{ACKNOWLEDGEMENTS}

We thank Prof. Giovanni Meola and his collaborators for providing us with muscle biopsies and for helpful discussion. M.G. is a PhD student in receipt of a fellowship from the Dottorato di Ricerca in Biologia Cellulare (University of Pavia). 


\section{REFERENCES}

Bachinski LL, Udd B, Meola G, Sansone V, Bassez G, Eymard B, Thornton CA, Moxley RT, Harper PS, Rogers MT, Jurkat-Rott K, Lehmann-Horn F, Wieser T, Gamez J, Navarro C, Bottani A, Kohler A, Shriver MD, Sallinen R, Wessman M, Zhang S, Wright FA, Krahe R, 2003. Confirmation of the type 2 myotonic dystrophy (CCTG)n expansion mutation in patients with proximal myotonic myopathy/proximal myotonic dystrophy of different European origins: a single shared haplotype indicates an ancestral founder effect. Am J Hum Gen 73:835-48.

Bernhard W, 1969. A new staining procedure for electron microscopical cytology. J Ultrastruct Res 27:250-65.

Bertoni-Freddari C, Fattoretti P, Malatesta M, 2004. Increased intracellular ionic content is correlated with a decreased perichromatin granule density in old neurones. Ann N Y Acad Sci 1030:289-96.

Biggiogera M, Bottone MG, Scovassi AI, Soldani C, Vecchio L, Pellicciari C, 2004. Rearrangement of nuclear ribonucleoprotein (RNP)-containing structures during apoptosis and transcriptional arrest. Biol Cell 96:603-15.

Biggiogera M, Cisterna B, Spedito A, Vecchio L, Malatesta M, 2008. Perichromatin fibrils as early markers of transcriptional alterations. Differentiation 76:57-65.

Bogolyubov D, Stepanova I, Parfenov V, 2009. Universal nuclear domains of somatic and germ cells: some lessons from oocyte interchromatin granule cluster and Cajal body structure and molecular composition. Bioessays 31:400-9.

Brook JD, McCurrach ME, Harley HG, Buckler AJ, Church D, Aburatani H, Hunter K, Stanton VP, Thirion JP, Hudson T, Sohn R, Zemelman B, Snell RG, Rundle SA, Crow S, Davies J, Shelbourne P, Buxton J, Jones C, Juvonen V, Johnson K, Harper PS, Shaw DJ, Housman DE, 1992. Molecular basis of myotonic dystrophy: expansion of a trinucleotide (CTG) repeat at the 3' end of a transcript encoding a protein kinase family member. Cell 69:385-7.

Cardani R, Mancinelli E, Giagnacovo M, Sansone V, Meola G, 2009. Ribonuclear inclusions as biomarker of myotonic dystrophy type 2, even in improperly frozen or defrozen skeletal muscle biopsies. Eur J Histochem 53:107-11.

Cardani R, Mancinelli E, Rotondo G, Sansone V, Meola G, 2006. Muscleblind-like protein 1 nuclear sequestration is a molecular pathology marker of DM1 and DM2. Eur J Histochem 50:177-82.

Cardani R, Mancinelli E, Sansone V, Rotondo G, Meola G, 2004. Biomolecular identification of (CCTG)n mutation in myotonic dystrophy type 2 (DM2) by FISH on muscle biopsy. Eur J Histochem 48:437-42.

Cardinale S, Cisterna B, Sonetti P, Aringhieri C, Biggiogera M, Barabino SML, 2007. Subnuclear localization and dynamics of the pre-mRNA 3' end processing factor CFI ${ }_{m}$ 68. Mol Biol Cell 18:1282-92. 
Cmarko D, Verschure PJ, Martin TE, Dahmus ME, Krause S, Fu XD, van Driel R, Fakan, S, 1999. Ultrastructural analysis of transcription and splicing in the cell nucleus after bromo-UTP microinjection. Mol Biol Cell 10:211-23.

Cruz-Jentoft AJ, Baeyens JP, Bauer JM, Boirie Y, Cederholm T, Landi F, Martin FC, Michel JP, Rolland Y, Schneider SM, Topinková E, Vandewoude M, Zamboni M; European Working Group on Sarcopenia in Older People, 2010. Sarcopenia: European consensus on definition and diagnosis: Report of the European Working Group on Sarcopenia in Older People. Age Ageing 39:412-23.

Day JW, Ricker K, Jacobsen JF, Rasmussen LJ, Dick KA, Kress W, Schneider C, Koch MC, Beilman GJ, Harrison AR, Dalton JC, Ranum LP, 2003. Myotonic dystrophy type 2: molecular, diagnostic and clinical spectrum. Neurology 60:657-64.

Edstrom E, Altun M, Bergman E, Johnson H, Kullberg S, Ramírez-León V, Ulfhake B, 2007. Factors contributing to neuromuscular impairment and sarcopenia during aging. Physiol Behav 92:129-35.

Fakan S, 1994. Perichromatin fibrils are in situ forms of nascent transcriptions. Trend Cell Biol 4:86-90.

Fakan S, 2004. Ultrastructural cytochemical analyses of nuclear functional architecture. Eur J Histochem 48:5-14.

Fardaei M, Rogers MT, Thorpe HM, Larkin K, Hamshere MG, Harper PS, Brook JD, 2002. Three proteins, MBNL, MBLL and MBXL, co-localize in vivo with nuclear foci of expanded-repeat transcripts in DM1 and DM2 cells. Hum Mol Genet 11:805-14.

Fu YH, Pizzuti A, Fenwick RG Jr, King J, Rajnarayan S, Dunne PW, Dubel J, Nasser GA, Ashizawa T, de Jong P, Wieringa B, Korneluk R, Perryman MB, Epstein $\mathrm{HF}$, Caskey CT, 1992. An unstable triplet repeat in a gene related to myotonic muscular dystrophy. Science 255:1256-8.

Giagnacovo M, Costanzo M, Cardani R, Veneroni P, Pellicciari C, Meola G, 2011. In vitro aging of myotubes derived from myoblasts of patients affected by myotonic dystrophy type 2 (DM2): ultrastructural evidence. Microscopie 16:60-7.

Giagnacovo M, Malatesta M, Cardani R, Meola G, Pellicciari C, 2012. Nuclear ribonucleoprotein-containing foci increase in size in non-dividing cells from patients with myotonic dystrophy type 2. Histochem Cell Biol 138:699-707.

Holt I, Jacquemin V, Fardaei M, Sewry CA, Butler-Browne GS, Furling D, Brook JD, Morris GE, 2009. Muscleblind-like proteins: similarities and differences in normal and myotonic dystropby muscle. Am J Pathol 174:216-27.

Huichalaf C, Sakai K, Jin B, Jones K, Wang GL, Schoser B, Schneider-Gold C, Sarkar P, Pereira-Smith OM, Timchenko N, Timchenko L, 2010. Expansion of CUG $R N A$ repeats causes stress and inbibition of translation in myotonic dystrophy 1 (DM1) cells. FASEB J 24:3706-19.

Jones K, Jin B, Iakova P, Huichalaf C, Sarkar P, Schneider-Gold C, Schoser B, Meola G, Shyu A.B, Timchenko N, Timchenko L, 2011. RNA Foci, CUGBP1, and ZNF9 Are the Primary Targets of the Mutant CUG and CCUG Repeats Expanded in Myotonic Dystrophies Type 1 and Type 2. Am J Pathol 179:2475-89.

Koopman R, van Loon LJC, 2009. Aging, exercise and muscle protein metabolism. J Appl Physiol 106:2040-8. 
Ladd AN, Charlet N, Cooper TA, 2001. The CELF family of RNA binding proteins is implicated in cellspecific and developmentally regulated alternative splicing. Mol Cell Biol 21:1285-96.

Lafarga M, Berciano MT, Andres MA, 1993. Protein-synthesis inbibition induces perichromatin granule accumulation and intranuclear rodlet formation in osmotically stimulated supraoptic neurons. Anat Embryol 187:363-9.

Liquori CL, Ricker K, Moseley ML, Jacobsen JF, Kress W, Naylor SL, Day JW, Ranum LP, 2001. Myotonic dystrophy type 2 caused by a CCTG expansion in intron 1 of ZNF9. Science 293:864-7.

Llorian M, Smith CWJ, 2011. Decoding muscle alternative splicing. Curr Opin Genet Develop 21:380-7.

Mahadevan M, Tsilfidis C, Sabourin L, Shutler G, Amemiya C, Jansen G, Neville C, Narang M, Barceló J, O'Hoy K, Leblond S, Earle-MacDonald J, de Jong PJ, Wieringa B, Korneluk RG, 1992. Myotonic dystrophy mutation: an unstable CTG repeat in the 3' untranslated region of the gene. Science 255:1253-5.

Malatesta M, Baldelli B, Battistelli S, Fattoretti P, Bertoni-Freddari C, 2005. Aging affects the distribution of the circadian CLOCK protein in rat hepatocytes. Microsc Res Tech 68:45-50.

Malatesta M, Bertoni-Freddari C, Fattoretti P, Baldelli B, Fakan S, Gazzanelli G, 2004. Aging and vitamin E deficiency are responsible for altered RNA pathways. Ann N Y Acad Sci 1019:379-82.

Malatesta M, Bertoni-Freddari C, Fattoretti P, Caporaloni C, Fakan S, Gazzanelli G, 2003. Altered RNA structural constituents in aging and vitamin E deficiency. Mech Ageing Dev 124:175-81.

Malatesta M, Biggiogera M, Cisterna B, Balietti M, Bertoni-Freddari C, Fattoretti P, 2010a. Perichromatin fibrils accumulation in hepatocyte nuclei reveals alterations of pre-mRNA processing during ageing. DNA Cell Biol 29:49-57.

Malatesta M, Fattoretti P, Baldelli B, Battistelli S, Balietti M, Bertoni-Freddari C, 2007. Effects of ageing on the fine distribution of the circadian CLOCK protein in reticular formation neurons. Histochem Cell Biol 127:641-7.

Malatesta M, Fattoretti P, Giagnacovo M, Pellicciari C, Zancanaro C, 2011a. Physical training modulates structural and functional features of cell nuclei in type II myofibers of old mice. Rejuvenation Res 14:543-52.

Malatesta M, Giagnacovo M, Cardani R, Meola G, Pellicciari C, 2011b. RNA processing is altered in skeletal muscle nuclei of patients affected by myotonic dystrophy. Histochem. Cell Biol 135:419-25.

Malatesta M, Giagnacovo M, Renna LV, Cardani R, Meola G, Pellicciari C, 2011c. Cultured myoblasts from patients affected by myotonic dystrophy type 2 exhibit senescence-related features: ultrastructural evidence. Eur J Histochem 55:e26.

Malatesta M, Meola G, 2010. Structural and functional alterations of the cell nucleus in skeletal muscle wasting: the evidence in situ. Eur J Histochem 54:e44.

Malatesta M, Perdoni F, Muller S, Pellicciari C, Zancanaro C, 2010b. Pre-mRNA processing is partially impaired in satellite cell nuclei from aged muscles. J Biomed Biotechnol 2010:410405.

Malatesta M, Perdoni F, Muller S, Zancanaro C, Pellicciari C, 2009. Nuclei of aged 
myofibres undergo structural and functional changes suggesting impairment in RNA processing. Eur J Histochem 53:97-106.

Malatesta M, Biggiogera M, Baldelli B, Barabino SML, Martin TE, Zancanaro C, 2008. Hibernation as a far-reaching program for the modulation of RNA transcription. Microsc Res Tech 71:564-72.

Mankodi A, Teng-Umnuay P, Krym M, Henderson D, Swanson M, Thornton CA, 2003. Ribonuclear inclusions in skeletal muscle in myotonic dystrophy types 1 and 2. Ann Neurol 54:760-8.

Mankodi A, Urbinati CR, Yuan QP, Moxley RT, Sansone V, Krym M, Henderson D, Schalling M, Swanson MS, Thornton CA, 2001. Muscleblind localizes to nuclear foci of aberrant RNA in myotonic dystrophy types 1 and 2. Hum Mol Genet 10:2165-70.

Mankodi A, Lin XL, Blaxall BC, Swanson MS, Thornton CA, 2005. Nuclear RNA foci in the heart in myotonic dystrophy. Circ Res 97:1152-5.

Meola G, Moxley RT 3 ${ }^{\text {rd }}$, 2004. Myotonic dystrophy type 2 and related myotonic disorders. J Neurol 251:1173-82.

Miller JW, Urbinati CR, Teng-Umnuay P, Stenberg MG, Byrne BJ, Thornton CA, Swanson MS, 2000. Recruitment of human muscleblind proteins to (CUG)(n) expansions associated with myotonic dystrophy. EMBO J19:4439-48.

Monneron A, Bernhard W, 1969. Fine structural organization of the interphase nucleus in some mammalian cells. J Ultrastruct Res 27:266-88.

Perdoni F, Malatesta M, Cardani R, Giagnacovo M, Mancinelli E, Meola G, Pellicciari C, 2009. RNA/MBNL1-containing foci in myoblast nuclei from patients affected by myotonic dystropby type 2: an immunocytochemical study. Eur J Histochem 53:151-8.

Puvion E, Puvion-Dutilleul F, 1996. Ultrastructure of the nucleus in relation to transcription and splicing: roles of perichromatin fibrils and interchromatin granules. Exp Cell Res 229:217-25.

Puvion E, Viron A, Bernhard W, 1977. Unusual accumulation of ribonucleoprotein constituents in the nucleus of cultured rat liver cells after hypothermal shock. Biol Cell 29:81-8.

Puvion-Dutilleul F, Puvion E, 1981. Relationship between chromatin and perichromatin granules in cadmium-treated isolated hepatocytes. J Ultrastruct Res 7:341-50.

Ranum LP, Rasmussen PF, Benzow KA, Koob MD, Day JW, 1998. Genetic mapping of a second myotonic dystropby locus. Nat Genet 19:196-8.

Ryall JG, Schertzer JD, Lynch GS, 2008. Cellular and molecular mechanisms underlying age-related skeletal muscle wasting and weakness. Biogerontol 9:213-28.

Salisbury E, Schoser B, Schneider-Gold C, Wang GL, Huichalaf C, Jin B, Sirito M, Sarkar P, Krahe R, Timchenko NA, Timchenko LT, 2009. Expression of RNA CCUG repeats dysregulates translation and degradation of proteins in myotonic dystrophy 2 patients. Am J Pathol 175:748-62.

Savkur RS, Philips AV, Cooper TA, 2001. Aberrant regulation of insulin receptor alternative splicing is associated with insulin resistance in myotonic dystrophy. Nat Genet 29:40-7.

Savkur RS, Philips AV, Cooper TA, Dalton JC, Moseley ML, Ranum LP, Day JW, 2004. 
Insulin receptor splicing alteration in myotonic dystrophy type 2. Am J Hum Genet 74:1309-13.

Schoser BGH, Schneider-Gold C, Kress W, Go Ebel HH, Toyka KV, Lochmuller H, Ricker K, 2004. Muscle pathology in 57 patients with myotonic dystrophy type 2. Muscle Nerve 29:275-81.

Schul W, Groenhout B, Koberna K, Takagaki Y, Jenny A, Manders EM, Raska I, van Driel, R, de Jong L, 1996. The RNA 3' cleavage factors CstF 64 kDa and CPSF $100 \mathrm{kDa}$ are concentrated in nuclear domains closely associated with coiled bodies and newly synthesized RNA. Embo J 15:2883-92.

Taneja KL, McCurrach M, Schalling M, Housman D, Singer RH, 1995. Foci of trinucleotide repeat transcripts in nuclei of myotonic dystropby cells and tissues. J Cell Biol 128:995-1002.

Thompson LD, 2009. Age-related muscle dysfunction. Exp Gerontol 44:106-11.

Vihola A, Bassez G, Meola G, Zhang S, Haapasalo H, Paetau A, Mancinelli E, Rouche A, Hogrel JY, Laforêt P, Maisonobe T, Pellissier JF, Krahe R, Eymard B, Udd B, 2003. Histopathological differences of myotonic dystropby type 1 (DM1) and PROMM/DM2. Neurology 60:1854-7.

Wahle E, Rüegsegger U, 1999. 3'-end processing of pre-mRNA in eukaryotes. FEMS Microbiol Rev 23:277-95.

Wheeler TM, Thornton CA, 2007. Myotonic dystrophy: RNA-mediated muscle disease. Curr Opin Neurol 20:572-6.

Zancanaro C, Malatesta M, Vogel P, Osculati F, Fakan S, 1993. Ultrastructural and morphomentrical analyses of the brown adipocyte nucleus in a bibernating dormouse. Biol Cell 79:55-61. 